\title{
Relations fecal coliforms/ fecal Streptococci as indicators of the origin of fecal pollution in urban and rural water bodies of Temuco, Chile
}

\author{
Reinaldo Rivera, Patricio de Los Ríos, and Ángel Contreras \\ Escuela de Ciencias Ambientales, Facultad de Recursos Naturales, Universidad Católica de Temuco, Casilla \\ 15-D, Temuco.
}

\begin{abstract}
R. Rivera, P. de Los Ríos, and Á. Contreras. 2010. Relations fecal coliforms/ fecal Streptococci as indicators of the origin of fecal pollution in urban and rural water bodies of Temuco, Chile. Cien. Inv. Agr. 37(2): 141-149. The presence of alloctone bacteria is considered as one of the more important biological pollutants of water bodies, existing one close relation between the fecal contamination indicators and the existence of urban and industrial zones. In the present study we utilized indicators of fecal contamination (coliforms and streptococci) and the coliform/streptococci index (FC/FE) for determine the origin of fecal pollution in two water bodies of Temuco, Northern Campus at north surrounding of Temuco, and Rucamanque source that is located in a rural zone. It utilized the multiple assays number for obtain the bacteria more probable number in $100 \mathrm{ml}$ of water sample. It was done the correlations between microbiological indicators and physic-chemical variables. The results indicate that both sites have low fecal contamination. It was reported important correlation between fecal coliforms, temperature and $\mathrm{pH}$, but negative correlations with dissolved oxygen. The index (FC/FE) was correlated only with dissolved oxygen. The temperature would have an important regulator role in the coliform growth, whereas the fecal streptococci have high densities at low values of temperature, conductivity and dissolved oxygen. The origin of microbiological pollution was related with the antrophogenic intervention in both studied sited, human origin in Northern Campus, and mixed origin in Rucamanque source. It was suggest the use of index as first approach for identify the origin of fecal pollution.
\end{abstract}

Key words: Fecal pollution, fecal indicator, coliforms, streptococci.

\section{Introduction}

Characteristics of the aquatic environment are in a large extent determined by the properties and activity of microorganisms. However, the presence of alloctone bacteria is regarded as

Received July 07, 2009. Accepted August 19, 2009. Corresponding author: reijavier@gmail.com one of the most important biological contaminants in aquatic systems, with a close relation between the increase of fecal bacteria and the closeness to urban and industrial centers (Martínez et al., 1993).

The microbiological indicators frequently used in quality evaluations of continental waters correspond to fecal coliform bacteria, Escherichia coli, fecal streptococci and spores of sulfite-reductor anaerobes (Wyer et al., 1995; Gesche et 
al., 2003). Unlike pathogenic bacteria, indicator bacteria may be easily detected and quantified by simple and economic methods (Murgel, 1984), allowing the sanitary classification of water for different uses, the determination of criteria and compliance of quality standards, the identification of contaminant discharges, the control of processes of water treatment, and epidemiological studies among others (EPA, 1997; Gesche et al., 2003; Horan, 2003). However, there is no universal indicator group of fecal contamination; therefore, the appropriate bacterial group must be selected for the specific situation under study (Suárez, 2002).

In Chile, the microbiological indicators of contamination for surface waters correspond to the coliform group (e.g., INN, 1978; Ministerio Secretaría General de la Presidencia, 2001; CONAMA 2004; INN, 2005), which are conformed by bacillary bacteria, facultative aerobes and anaerobes, negative Gram, non-spore-forming and lactose fermenters, corresponding approximately to $10 \%$ of human and animal intestinal microorganisms (Mariñelarena and Mariazzi, 1995; Romero, 1999; Prescott et al., 2004). The presence of these bacteria is considered as an index of fecal contamination and therefore contamination with pathogenic organisms (Sankararamakrishnan and Guo, 2005; Bastholm et al., 2008).

In regard to the determination of the animal or human origin of the contamination, it is proposed the use of fecal streptococci, bacterial group comprising several species of the genera Enterococcus and Streptococcus (Suárez, 2002; Horan, 2003). Fecal streptococci include species found in feces from humans and hot-blooded animals (Sinton et al., 1993). They present survival rates similar to enteric pathogens and they do not proliferate in the environment (Horan, 2003). Fecal streptococci have been used by sanitary authorities in different countries to evaluate the quality of their water resources, along with fecal coliforms to differentiate the fecal contamination of human and animal origin (Marín, 2003; Sankararamakrishnan and Guo, 2005). However, factors like the differences in mortality ranges in the environment between these two bacterial groups, variable survival of streptococci species and methods for determination questioned their use for these purposes (Sinton et al., 1993; Marín, 2003). Nevertheless, the fecal coliform /fecal streptococci relation to differentiate contamination has been used essentially in tropical zones, and the application in template zones is still unknown (Chagas et al., 2006).

The objective of the present study was to evaluate the source of microbiological contamination through the relation $\mathrm{FC} / \mathrm{FE}$ in two bodies of water, one located in an urban zone and the other located in a rural zone of the commune of Temuco, Region of La Araucanía.

\section{Materials and methods}

\section{Sites under study}

The first site corresponded to the urban Lagoon Northern Campus, located in a campus of Catholic University of Temuco (Table 1). The origins of the lagoon date back to the late nineties where it was the extension of a small wetland. The second site corresponded to the water intake of the Rucamanque land, located at $12 \mathrm{~km}$ North West from the city of Temuco, Region of La Araucanía, Chile (Table 1). The intake is surrounded by native relict forests in the Central Valley (Ramírez et al., 1988). The hillsides of the Rucamanque land are drained by the Chivilcán creek, where an intake was built in 1931 to provide water to the city of Temuco (Magofke, 1985).

The criteria applied for the sites selection consisted on their anthropic intervention, as well as their artificial origin. The Lagoon Northern Campus is located inside the city and highly influenced by anthropic activities from urban zones, unlike the intake in the Rucamanque land, which is located in a natural environment away from urban centres; therefore, a minimal alteration is expected. The main morphometric characteristics of both sites are detailed in Table 1. 
Table 1. Morphometric parameters of studied water bodies.

\begin{tabular}{lcc}
\hline & Lagoon Northern Campus & Rucamanque source \\
\hline Latitude S. & $38^{\circ} 42^{\prime} 11^{\prime \prime}$ & $38^{\circ} 39^{\prime} 54^{\prime \prime}$ \\
Longitude W. & $72^{\circ} 32^{\prime} 50^{\prime \prime}$ & $72^{\circ} 36^{\prime} 11^{\prime \prime}$ \\
Altitude (m). & 129 & 107 \\
Surface (m $\left.{ }^{2}\right)$. & 4.990 & 49.5 \\
Maximum length (m). & 69.1 & 11.0 \\
Maximum width (m). & 19.6 & 7.0 \\
Maximum depth (m) & 1.3 & 1.0 \\
\hline
\end{tabular}

\section{Physical-chemical variables}

The water temperature, $\mathrm{pH}$, electric conductivity and oxygen dissolved in both bodies of water were measured in situ by digital instruments. The samples were taken in fall and summer as they are periods where the lowest and highest environmental temperatures are present in the sites under study. The samples collection for physical-chemical variables was made in the deepest zone (Sosnovsky and Quirós, 2006).

\section{Microbiological analysis}

The concentration of total coliform bacteria (TC), fecal coliforms (FC) and fecal streptococci (FS) were quantified through the fermentation technique in multiple tubes (APHA, 1992; Astorga et al., 1998), with three dilutions and three replications per site. The samples were collected in 1-liter-sterile flasks, which were transported to the Microbiology Laboratory of Catholic University of Temuco in a thermal container for analysis.

An aliquot was inoculated for the TC and FC quantification with a nichrome loop from each sample in tubes with lauryl sulfate broth, and incubated for 48 hours at $35 \pm 1^{\circ} \mathrm{C}$. The positive tubes were inoculated in tubes of brilliant green bile broth (BGB) selective for coliform bacteria. The formation of turbidity and gas in 48 hours, at $35 \pm 1^{\circ} \mathrm{C}$ confirmed the presence of TC. At the same time, FC bacteria were confirmed, as an aliquot of positive lauryl sulfate broth was inoculated in tubes with EC broth (Escherichia coli). The production of turbidity and gas in 48 hours of incubation at $44.5^{\circ} \mathrm{C}$ confirmed the presence of this group (Astorga et al., 1998). The cultivation medium manifesting gas production as a consequence of lactose fermentation was considered positive (Gesche et al., 2003).

FE quantification was made by the procedure described by Fernández et al. (2007). The samples were inoculated in tubes with glucose azide broth and incubated at $37 \pm 1{ }^{\circ} \mathrm{C}$ during 48 hours. The tubes presenting turbidity were transferred to tubes with broth of bromocresol purple cultivation. At 48 hours, the tubes presenting turbidity and change from purple to green yellow were considered positive.

The calculation of concentration TC, FC and FE bacteria was determined based on tables of most probable numbers (NMP), expressing the results as NMP/100 $\mathrm{ml}$ of water (Mariñelarena and Mariazzi, 1995; Astorga et al., 1998).

\section{Source of microbiological contamination}

The determination of the source of fecal contamination was determined by the relation fecal coliform /fecal streptococci (FC/FE) established by Geldreich and Kenner (1969). It indicates human origin if the relation $\mathrm{FC} / \mathrm{FE}>4.0$, it indicates animal origin if the relation $\mathrm{FC} / \mathrm{FE}<$ 0.7 . The interval $<4.0$ and $>0.7$ was considered as a mixed contamination.

\section{Statistical analysis}

The microbiological variables TC, FC, FE and the relation $\mathrm{FC} / \mathrm{FE}$ measured in both sites were 
Table 2. Physico-chemical and microbiological parameters described in the studied sites (average + standard deviation) and correlation index ("p" values $\leq 0.05$ denoted significant correlations*). Abbreviations: $\mathrm{DO}=$ dissolved oxygen; TC= total coliforms; $\mathrm{FC}=$ fecal coliforms; $\mathrm{FE}=$ fecal streptococci.

\begin{tabular}{|c|c|c|c|c|c|c|c|c|}
\hline Site & Period & $\begin{array}{c}\text { Temperature } \\
\left({ }^{\circ} \mathrm{C}\right)\end{array}$ & $\begin{array}{c}\text { Conductivity } \\
(\mu \mathrm{S} / \mathrm{cm})\end{array}$ & $\begin{array}{c}\mathrm{pH} \\
\text { (Unit) }\end{array}$ & $\begin{array}{c}\mathrm{DO} \\
\left(\mathrm{mgL}^{-1}\right)\end{array}$ & $\begin{array}{c}\mathrm{TC} \\
\text { (MPN/100 ml) }\end{array}$ & $\begin{array}{c}\mathrm{FC} \\
(\mathrm{MPN} / 100 \mathrm{ml})\end{array}$ & $\begin{array}{c}\mathrm{FE} \\
(\mathrm{MPN} / 100 \mathrm{ml})\end{array}$ \\
\hline \multirow{2}{*}{$\begin{array}{l}\text { Rucamanque } \\
\text { source }\end{array}$} & Summer & $13.3 \pm 0.12$ & $43.4 \pm 0.60$ & $6.5 \pm 0.09$ & $7.6 \pm 0.14$ & $38.3 \pm 5.33$ & $38.3 \pm 5.33$ & $19.3 \pm 3.93$ \\
\hline & Autumn & $12.5 \pm 0.95$ & $57.9 \pm 0.85$ & $6.6 \pm 0.05$ & $5.8 \pm 0.16$ & $673.3 \pm 465.09$ & $166.7 \pm 31.80$ & $81.0 \pm 27.73$ \\
\hline \multirow{3}{*}{$\begin{array}{l}\text { Lagoon Northern } \\
\text { Campus }\end{array}$} & Summer & $21.9 \pm 0.31$ & $74.3 \pm 0.40$ & $7.7 \pm 0.05$ & $7.9 \pm 0.16$ & $793.3 \pm 126.67$ & $466.7 \pm 226.67$ & $1.3 \pm 0.67$ \\
\hline & Autumn & $19.8 \pm 0.10$ & $102.7 \pm 0.81$ & $8.7 \pm 0.08$ & $8.0 \pm 0.17$ & $540.0 \pm 0.0$ & $43.0 \pm 18.58$ & $8.9 \pm 2.07$ \\
\hline & & \multicolumn{2}{|r|}{ Temperature } & \multicolumn{2}{|r|}{ Conductivity } & \multicolumn{2}{|l|}{$\mathrm{pH}$} & DO \\
\hline \multicolumn{9}{|c|}{ Lagoon Northern Campus } \\
\hline \multicolumn{2}{|l|}{ Total coliforms } & \multicolumn{2}{|r|}{-0.492} & \multicolumn{2}{|r|}{0.027} & \multicolumn{2}{|l|}{0.617} & 0.410 \\
\hline \multicolumn{2}{|l|}{ Fecal coliforms } & \multicolumn{2}{|r|}{-0.539} & \multicolumn{2}{|r|}{0.187} & \multicolumn{2}{|l|}{$0.714 *$} & 0.315 \\
\hline \multicolumn{2}{|c|}{ Fecal streptococci } & \multicolumn{2}{|r|}{$0.910^{*}$} & \multicolumn{2}{|r|}{0.410} & \multicolumn{2}{|l|}{-0.464} & $-0.761^{*}$ \\
\hline \multicolumn{2}{|c|}{ Relationship FC/FE } & \multicolumn{2}{|r|}{-0.664} & & -0.051 & \multicolumn{2}{|l|}{0.621} & 0.492 \\
\hline \multicolumn{9}{|c|}{ Rucamanque source } \\
\hline \multicolumn{2}{|l|}{ Total coliforms } & \multicolumn{2}{|r|}{$0.693 *$} & & 0.539 & \multicolumn{2}{|l|}{$0.675^{*}$} & $-0.783^{*}$ \\
\hline \multicolumn{2}{|l|}{ Fecal coliforms } & \multicolumn{2}{|r|}{$0.762 *$} & & 0.077 & \multicolumn{2}{|l|}{0.633} & -0.494 \\
\hline \multicolumn{2}{|c|}{ Fecal streptococci } & \multicolumn{2}{|r|}{0.638} & & 0.349 & \multicolumn{2}{|l|}{$0.936^{*}$} & -0.509 \\
\hline \multicolumn{2}{|c|}{ Relationship FC/FE } & \multicolumn{2}{|r|}{0.328} & & 0.519 & \multicolumn{2}{|l|}{-0.009} & $-0.729 *$ \\
\hline
\end{tabular}

compared by the non parametric Mann-Whitnney test. The microbiological indicators were correlated with the physical-chemical parameters from both periods by the Spearman non parametric correlation coefficient (Zar, 1999). The analyses were made by the XLSTAT software, version 7.5.2. (www.addinsoft.com).

\section{Results}

The average and standard error of the microbiological and physical-chemical variables of the sites under study are presented in Table 2, as well as the correlations existing among them.

The microbiological analysis carried out for the summer and fall seasons in both sites (Table 2) is not an indication of a tendency of the TC and FC bacteria in the studied periods. The concentration of TC bacteria, in both the Rucamanque intake and the Lagoon Northern Campus was remarkably higher than the FC concentration, especially for fall. In regard to the FE, the highest concentrations were recorded in the Rucamanque intake, in both summer and fall, coinciding with lower values of temperature, conductivity, $\mathrm{pH}$ and dissolved oxygen compared to the higher values in the Lagoon Northern Campus in both periods.

The analysis of correlation on the variables quantified in the Lagoon Northern Campus showed high relations between $\mathrm{FC}$ and $\mathrm{pH}$. The indicator group conformed by FE showed significant and positive correlations with temperature, but negatively with the DO. The analysis of correlation in the Rucamanque intake revealed that the TC were positively and significantly correlated with the temperature and the $\mathrm{pH}$ (Table 2), but negatively although significantly with the dissolved oxygen. In regard to the FC 
quantified in the intake, a significant correlation with the temperature was observed. Likewise, the FE showed a high correlation with the $\mathrm{pH}$. The relation FC/FE revealed a correlation with the DO, although negatively (Table 2).

In regard to the source of microbiological contamination (Table 3), it was observed that the sites under study presented a defined pattern in both sampling periods, corresponding to human origin in the Lagoon Northern Campus (FC/FE $>4.0)$ and mixed contamination in the Rucamanque intake (FC/FE $>0.7$ and $<4.0$ ), and the source of contamination for this site was not identified.

Table 3. Origin of bacteriological pollution of the studied sites (average \pm standard error).

\begin{tabular}{llll}
\hline Site & Period & FC/FE & Origin \\
\hline $\begin{array}{l}\text { Rucamanque } \\
\text { source }\end{array}$ & Summer & $2.0 \pm 0.16$ & Mixed \\
Lagoon & Autumn & $3.2 \pm 2.9$ & Mixed \\
$\begin{array}{l}\text { Northern } \\
\text { Campus }\end{array}$ & Summer & $273.3 \pm 172.4$ & Anthropic \\
& Autumn & $5.9 \pm 5.2$ & Anthropic \\
\hline
\end{tabular}

The comparative analysis (Table 4) revealed that the TC and FE bacteria present significant differences in the sites under study $(\mathrm{p}<0.05$ and $p<0.004$ respectively). However, the FC bacteria and the relation $\mathrm{FC} / \mathrm{FE}$ might indicate a similar contribution from fecal bacteria in both the Rucamanque intake and the Lagoon Northern Campus, due to the absence of significant differences $(p<0.581$ and $p<0.055$ respectively).

Table 4. Comparison between microbiological variables in Rucamanque source and lagoon at Northern Campus of the Catholic University of Temuco.

\begin{tabular}{lll}
\hline Indicator & Observed Z value & P value \\
\hline Total coliforms & 1.963 & $0.050^{*}$ \\
Fecal coliforms & 0.646 & 0.518 n.s. \\
Fecal streptococci & -2.892 & $0.004^{* *}$ \\
Relationship FC/FE & 1.922 & 0.055 n.s. \\
\hline
\end{tabular}

\section{Discussion}

The pristine site versus contaminated site criterion fixed a priori was not corroborated by the indicators of FC microbiological contamination and the relation $\mathrm{FC} / \mathrm{FE}$, due to the absence of significant differences, which indicates similar contributions of fecal matter in the bodies of water. However, the FE density, was higher in the Rucamanque intake, supported by a significant difference $Z=-2.892 \mathrm{p}<0.004$ ), which generates the differentiating element in the bodies of water. Nevertheless, the presence of FE could be related to contributions of fecal matter distant from the site where the samples were collected, situation described by Marín (2003), which does not necessarily involve recent fecal contamination in the intake.

It is noteworthy to remark the significant correlation between $\mathrm{TC}$ and the water temperature in the Rucamanque intake, which is coherent to the proposals by Atlas and Bartha (2002) on the close relation between bacteria and temperature. Similarly, a high correlation between the FE and temperature was recorded in the Lagoon Northern Campus, which may be explained by the FE physiology as they present higher resistance to the environmental stress (Godfree et al., 1997; Barrera et al., 1998). Even though there was a high water temperature, conductivity and $\mathrm{pH}$ during both sampling periods in the lagoon, these conditions might not represent extreme conditions for these microorganisms.

The bacterial group formed by the FC presented a higher density in the Lagoon Northern Campus for the summer season, which is related to the high environmental temperature (c.a $30{ }^{\circ} \mathrm{C}$, Ramírez, 2007), which is similar to the records by Fernández et al. (2007) for the El Sauce lagoon in the Argentinean pampas, and by Rivera et al. (2004) for the Cautín river in the zone bordering the city of Temuco. According to these last authors, the FC concentrations found in ritral zones of the Cautín river would be similar to the reports for the Rucamanque intake, which shows their relatively pristine character. 
In regard to the $\mathrm{TC}$, a higher concentration was recorded in both sites in comparison to the $\mathrm{FC}$, which is expected because the TC refer to the total of coliform bacteria from human, animal or edaphic origin (Romero, 1999). The FC did not present significant differences, which indicates that both bodies of water might receive similar bacterial contributions from the mentioned origins.

In Chile, only the TC and FC are used as parameters of microbiological evaluation, which must not exceed a value of $1000 \mathrm{NMP} / 100 \mathrm{ml}$ for irrigation or recreational purposes with direct contact (INN, 1978). This allows indicating that, based on the current regulation; the Rucamanque intake and the Lagoon Northern Campus would be adequate for the mentioned uses. In regard to the FE, Chile has regulations for determining these bacteria (INN, 2002) although unlike Central American countries, the $\mathrm{FE}$ have been regarded as indicators of fecal contamination, used along FC as differentiators of fecal contamination (Barrera et al., 1998; Suárez, 2002).

The determination of the source of fecal contamination allowed showing that the pattern of mixed contamination found in the Rucamanque intake considered as natural site, may be related to the existence of cattle and poultry existing in the land. The low density of fecal streptococci and FC/FE coefficients in the interval 0.7 and 4.0 might indicate that there are not any important contributions of fecal matter by home or wild animals. On the contrary, the Lagoon Northern Campus presented a microbial load of human origin, due to the relation $\mathrm{FC} / \mathrm{FE}$ that remarkably exceeded the value established by Geldreich and Kenner (1969) as fecal human contamination, which is expected due to the contributions to the lagoon tributary on the path for the urban zone of Temuco, as it was described by Habit et al. (2005) for the Quilque river in the city of Los Ángeles and by Martínez et al. (1993) for the Bío Bío river.

The use of the relation between the FC compared to the $\mathrm{FE}$ as a differentiating index of fecal contamination was common until recent years (Howell et al., 1996; Sankararamakrishnan and Guo, 2005). Nevertheless, the relation $\mathrm{FC} / \mathrm{FE}$ has involved questioning, due to the different indexes of survival in the species of fecal streptococci (Marín, 2003; Horan, 2003), as well as by the methods of FE count. This information was considered by standardizing the methodology for FC and FE quantification, using only the technique of multiple tubes to avoid errors in the bacterial count. The fact that the validity of the relation $\mathrm{FC} / \mathrm{FE}$ has been questioned mainly in tropical areas deserves special attention (Suárez, 2002). However, its use has not been rejected in temperate areas (Chagas et al., 2006) as made in this study.

If both antecedents are considered, the use of the relation FC/FE could represent the first approach in regard to the origin of the fecal contamination in the Central-South of the country, which has shown an increased on cattle activities in recent years (Alfaro and Salazar, 2005), where the aquatic systems were exposed to a higher contribution of waters contaminated with fecal matter of animal origin. Nevertheless, it becomes necessary to analyze the different genera and species composing the group of fecal enterococcus for a correct determination of the fecal origin of the contamination, by biochemical and/or serological tests which demand higher resources (e.g., financing, infrastructure) unlike the relation $\mathrm{FC} / \mathrm{FE}$, which may be made in laboratories with less equipment.

Based on the results obtained, we may conclude that: 1) the bacterial load indicates that both sites under study present a low fecal contamination, which might be adequate for irrigation or recreational use with direct contact, according to the current legislation. 2) The bacterial load was positive and significantly correlated to the temperature, and negatively with the dissolved oxygen, therefore, the temperature would regulate the bacterial load in both sites. 3) The higher FE concentration was recorded at lower values in the physical-chemical variables, which indicates a higher environmental tolerance unlike the coliform. 4) The relation FC/FE indicated fecal contamination from human origin for ur- 
ban environment and of mixed type in natural environment, with a relation between the load of fecal bacteria and the surroundings of both bodies of water.

\section{Acknowlegement}

The authors thank the School of Environmental Sciences of Catholic University of Temuco for the technical and financial facilities for the development of this work.

\title{
Resumen
}

\begin{abstract}
R. Rivera, P. de Los Ríos y Á. Contreras. 2010. Relación coliformes fecales/estreptococos fecales, como indicador del origen de la contaminación fecal en cuerpos de agua urbano y rural de la Comuna de Temuco, Chile. Cien. Inv. Agr. 37(2): 141-149. La presencia de bacterias alóctonas es considerada uno de los contaminantes biológicos más importantes de los sistemas acuáticos, existiendo una estrecha relación entre los indicadores de contaminación fecal y la existencia de centros urbanos e industriales. Se utilizaron indicadores de contaminación fecal (coliformes y estreptococos fecales), y el índice coliformes/estreptococos fecales para determinar la fuente de contaminación fecal en dos cuerpos de agua de la comuna de Temuco, Laguna Campus Norte, situada en zona urbana y bocatoma Rucamanque, ubicada en un sitio rural. Se utilizó la técnica de tubos múltiples para obtener el número más probable de bacterias en $100 \mathrm{ml}$ de agua. Se efectuaron correlaciones entre los indicadores microbiológicos y variables fisicoquímicas. Los resultados indican que ambos sitios presentaron baja contaminación fecal. Se reportan importantes correlaciones entre coliformes fecales, temperatura y $\mathrm{pH}$. Los estreptococos fecales exhibieron altas correlaciones con la temperatura y $\mathrm{pH}$, pero negativas con el oxígeno disuelto. El índice $\mathrm{CF} / \mathrm{FE}$ se correlacionó únicamente con el oxígeno disuelto. La temperatura jugaría un rol regulador en el crecimiento de los coliformes, en cambio los FE, presentan mayores densidades a menores valores de temperatura, $\mathrm{pH}$, conductividad y oxígeno disuelto. La fuente de contaminación microbiológica se relacionó con la intervención antrópica presente en los sitios, origen humano en laguna Campus Norte y origen mixto en bocatoma Rucamanque. Se recomienda el uso del índice como primera aproximación para identificar el origen de la contaminación fecal.
\end{abstract}

Palabras claves: Contaminación fecal, indicador fecal, coliformes, estreptococos.

\section{References}

Alfaro, M. and F. Salazar. 2005. Ganadería y contaminación difusa, implicancias para el sur de Chile. Agricultura Técnica 65 (3): 330-350.

APHA, 1992. Standard Methods for the examination of water and wastewater. American Public Health Association (APHA), American Water Works Association (AWWA) and Water Pollution Control Federation (WPCF), Washington DC. 1193 pp.

Astorga, J., S. Avendaño, S. Bengoa, A. Cordano, M. Inzunza, C. Jacob, L. López, E. Marambio, V.
Parada, and C. Venegoni. 1998. Manual de técnicas microbiológicas para alimentos y agua. Ed. Instituto de Salud Pública de Chile. Santiago. 95 pp.

Atlas, R., and R. Bartha. 2002. Ecología microbiana y microbiología ambiental. $4^{a}$ Edición. Pearson Educación. Madrid, España. 696 pp.

Barrera, G., I. Wong, A. Sobrino, X. Guzmán, F. Hernández, and F. Saavedra. 1998. Estudio preliminar de contaminación bacteriológica en la laguna Pueblo Viejo, Veracruz, México. Revista Internacional de Contaminación Ambiental. 14 (2): 63-68.

Bastholm, S., L. Wahlstrøm, L. Appel, and P. Roslev. 2008. A simple bioluminescence procedure 
for early warning detection of coliform bacteria in drinking water.World Journal of Microbiology and Biotechnology 24: 2323-2330.

Chagas, C., J. Morettón, O. Santanatoglia, M. Paz, H Muzio, M De Siervi, and M. Castiglioni. 2006. Indicadores de contaminación biológica asociados a la erosión hídrica en una cuenca de pampa ondulada Argentina. Ciencia del Suelo (Argentina) 24 (1): 21-27.

CONAMA, 2004. Guía para el establecimiento de las normas secundarias de calidad ambiental para aguas continentales superficiales y marinas. Comisión Nacional del Medio Ambiente. Gobierno de Chile. Santiago, Chile. $18 \mathrm{p}+$ anexos.

Fernández, C., C. Salerno, J. Paoloni, and G. Laurent. 2007. Water quality in a lagoon in the southeast pampa region of Argentina. Revista Argentina de Microbiología 39: 51-56.

Geldreich, E., and B. Kenner. 1969. Concepts of faecals streptococci in stream pollution. Journal of the Water Pollution Control Federation 41 (8): 336-352.

Gesche, E., A. Vallejos, and M. Sáez. 2003. Eficiencia de anaerobios sulfito-reductores como indicadores de calidad sanitaria de agua. Método de Número Más Probable (NMP) Archivos de Medicina Veterinaria 35 (1): 99-107.

Godfree, A., D. Kay, and M. Wyer. 1997. Fecal streptoccoci as indicator of fecal contamination in water. Journal of Applied Microbiology 83: 110-119.

Habit, E., O. Parra, and C. Valdovinos. 2005. Ictiofauna de un sistema fluvial receptor de aguas servidas: respuestas a una nueva planta de tratamiento (Río Quilque, Chile central). Gayana 69 (1): 94-103.

Horan, N. 2003. Fecal indicator organisms En: Mara D. and N. Horan (eds.). The Handbook of Water and Wastewater Microbiology: Academic Press London. p. 105-112.

Howell, J., M. Coyne, and P. Cornelius. 1996. Effect of Sediment Particle Size and Temperature on Fecal Bacteria Mortality Rates and the Fecal Coliform/Fecal Streptococci Ratio. Journal of Environmental Quality 25: 1216-1220.

INN. 1978. Requisitos de calidad de agua para diferentes usos. Norma Chilena 1333 Of. 1978. Instituto Nacional de Normalización. Santiago, Chile. 20 pp.

INN. 2002. Agua- Determinación de estreptococos fecales. Norma Chilena 2658 Of. 2002. Técnica de Número más probable (NMP). Instituto Nacional de Normalización.

INN. 2005. Agua potable. Parte I. Requisitos. Norma Chilena 409/1. Of. 2005. Instituto Nacional de Normalización. Santiago, Chile. 12 pp.

Magofke, J. 1985. Rucamanque: Un relicto de bosque nativo en Temuco, Chile. Revista Universidad de la Frontera 4: 65-72.

Marín, R. 2003. Fisicoquímica y microbiología de los medios acuáticos. Tratamiento y control de calidad de aguas. Ediciones Días de Santos. Madrid, España. 311 pp.

Mariñelarena, A., and A. Mariazzi. 1995. Cuantificación de bacterias indicadoras de contaminación fecal. In: E. Lopretto and G. Tell (eds.). Ecosistemas de aguas continentales, metodologías para su estudio: Tomo I. Editorial Sur, La Plata, Argentina. p. 95-103.

Martínez, M., T. Maugeri, M. Mondaca, M. Abarzua, H. Urrutia, and K. Paredes. 1993. Caracterización bacteriológica del río Bío Bío, VIII región, Chile, bacterias aeróbicas heterotróficas, biomasa y productividad bacteriana. In: F. Faranda and O. Parra (eds.). Evaluación de la calidad del agua y ecología del sistema limnético y fluvial del río Bío Bío. Serie monografías científicas. EULA. 12: 279-291.

Ministerio Secretaría General de la Presidencia. 2001. Decreto Supremo 90. Norma de emisión para la regulación de contaminantes asociados a las descargas de residuos líquidos a aguas marinas y continentales superficiales. Publicada en D.O. el 07/03/2001. Ministerio Secretaría General de la Presidencia. Santiago, Chile. 20 pp.

Murgel, S. 1984. Limnología sanitaria. Estudio de la polución de aguas continentales. Secretaría General de la OEA Programa regional de Desarrollo Científico y Tecnológico monografía $\mathrm{N}^{\circ} 28$. Washington. 79 pp.

Prescott, L., J. Harley, and D. Klein. 2004. Microbiología. Quinta edición. Mc Graw-Hill, 1240 pp.

Ramírez, M. 2007. Informe meteorológico de Temuco, Universidad Católica de Temuco, Chile. Available online at: http://www.uctemuco.cl/ meteorologia/ (Website accessed 3 April, 2008).

Ramírez, C., E. Hauenstein, D. Contreras, and J. San Martín. 1988. Degradación de la vegetación en la depresión intermedia de la Araucanía, Chile. Agro Sur 16 (1): 1-14.

Rivera, N., F. Encina, A. Muñoz, and P. Mejías. 2004. La calidad de las aguas en los ríos Cautín e Impe- 
rial, IX región, Chile. Información Tecnológica 15 (5): 89-101.

Romero, J. 1999. Calidad del agua. Segunda edición. Ediciones Alfaomega, México. 272 pp.

Sankararamakrishnan, N., and Q. Guo. 2005. Chemical tracers as indicator of human fecal coliforms at storm water outfalls. Environment International 31: 1133-1140.

Sinton, L., A. Donnison, and C. Hastie. 1993. Faecal streptococci as faecal pollution indicators: a review. Part II: Sanitary significance, survival, and use. New Zealand Journal of Marine and Freshwater Research 27: 117-137.

Sosnovsky, A., and R. Quirós. 2006. El estado trófico de pequeñas lagunas pampeanas, su relación con la hidrología y el uso de la tierra. Ecología Austral 16: 115-124.
Suárez, M. 2002. Tendencia actual del estreptococo como indicador de contaminación fecal. Revista Cubana de Higiene y Epidemiología 40 (1): 38-43.

Wyer, M., D. Kay, G. Jackson, H. Dawson, J Yeo, and L. Tanguy. 1995. Indicator organism sources and coastal water quality: a catchment study on the island of Jersey. Journal of Applied Bacteriology 78: 290-296.

EPA-Environmental Protection Agency. 1997. Volunteer Stream Monitoring: A Methods Manual. Available online at: http://www.epa.gov/volunteer/stream/stream.pdf (Website accessed 15 May, 2008).

Zar, J. 1999. Biostatistical Analysis. Prentice Hall, New Jersey USA. 663 pp. 